\title{
The Effect of Employee Engagement on the Relationship Between Leader-Member Exchange and Innovative Work Behaviour in Kenya
}

\author{
Kanake Mercy Kananu*, Kemboi Ambrose, Tenai Joel \\ Department of Management Science, School of Business and Economics, Moi University, Eldoret, Kenya \\ Email address: \\ mercykirimi2@gmail.com (K. M. Kananu) \\ ${ }^{*}$ Corresponding author \\ To cite this article: \\ Kanake Mercy Kananu, Kemboi Ambrose, Tenai Joel. The Effect of Employee Engagement on the Relationship Between Leader-Member \\ Exchange and Innovative Work Behaviour in Kenya. Journal of Business and Economic Development. Vol. 5, No. 3, 2020 , pp. 113-120. \\ doi: $10.11648 /$ j.jbed.20200503.11
}

Received: May 5, 2020; Accepted: June 8, 2020; Published: June 20, 2020

\begin{abstract}
This paper aimed to explore the mediating effect of employee engagement on the relationship between Leader-Member Exchange (LMX) on Innovative Work Behaviour (IWB) within Manufacturing Firms in Kenya. The study was based on a quantitative approach and a cross-sectional survey design. Data were collected using self-administered, closed-ended questionnaire using stratified and systematic sampling techniques from a sample size of 470 respondents from a population of 9915 employees drawn from manufacturing firms in Kenya. The data were analyzed using Statistical Package for Social Science (SPSS) vs 23 software and hypotheses tested using Hayes (2018) Process Macro v. 3.2 (Model 4). The findings revealed that leader-member exchange has positive statistical significant effect on employee engagement, which in turn has a positive significant effect on Innovative Work Behaviour. The findings further showed a partial mediating effect of employee engagement on the relationship between Leader-Member Exchange and Innovative Work Behaviour. This study contributes to knowledge by providing insight into the predictor of employee Innovative Work Behaviour. The study potentially acts as an avenue through which managers can build on employee engagement and their exchange with employees' to boost Innovative Work Behavior.
\end{abstract}

Keywords: Employee Engagement, Innovative Work Behavior, Leader-Member Exchange, Manufacturing Firms

\section{Introduction}

Innovative work behaviour has been recognized as a fundamental practice with the potential to provide solutions to emerging social and economic challenges and is therefore well poised to drive economic growth among organizations [1]. The argument advanced is that through IWB, firms maintain their competitiveness particularly in today's competitive global market and business environment. Indeed, scholars have demonstrated that IWB is all about employee behaviour directed towards the generation, introduction, and use of organizational procedures, processes, ideas or products; while at the same time encouraging the implementation of novel ideas generated amongst the employees, and which when adopted have potential to improve processes and products $[1,2]$.
Although IWB has been seen to improve organisations' productivity, this cannot happen without the inclusion of individuals. Innovation behaviour among employees is therefore associated with diverse factors. It is, for instance, argued that given the increasing significance of innovation in organizational competitiveness, the conditions made available through which employees can elicit, their innovative behaviour remain critical [3-5].

To gain such crucial contribution, previous studies argued that many human resource management factors contribute to IWB, and these factors need to be explored to bring more understanding on this matter [6]. Most of the past literature has investigated the linkage between IWB with practices used in the management of human resources (HRM); citizenship behaviour as portrayed within the organization; the exchange that exists between leaders and members; 
psychological empowerment; autonomy of the job, engagement, and job security [7].

A possible indicator of IWB is employee engagement which indicates that when employees have an affective and cognitive connection with their managers, they become great advocates of the organization to the customers and this leads to improvement of organisation outcomes [8]. It is argued that an engaged employee has a passion for the job and shows a strong connection to the organization [9].

The evidence existing in the extant literature confirms that managers are critical to employees' acquisition behaviour suited towards innovativeness in tasks assigned [10]. Dulebohn and colleagues contend that managers are in a position to nurture innovativeness among employees by providing the enabling environment and also giving the necessary treatment which can push employees creativity beyond the formal job contract. They argue further that, the relationship between managers and employees' helps the latter to be aware of the needs and expectations which might improve IWB. It is argued that by virtue of their position of influence, managers' decisions are bound to be antecedents of attitudes and behaviour that employees acquire.

A survey by the Kenya Association of Manufacturers [11] lauds Kenya's manufacturing sector for remaining fundamental in the alleviation of poverty in the country. KAM points out that the sector is a front runner in the sustenance of economic growth, poverty alleviation, and job creation. Moreover, the Economic survey underscores the sector's role in the stability of Kenya's economic development agenda which is leveraged upon foreign exchange and direct investment (Economic Survey, 2018).

In spite of the country seeking to boost the share that the manufacturing sector contributes to the GDP, KAM [12] acknowledges that in Kenya, the sector is also feeling the challenge arising due to globalization. Thus the current study sought to extend previous knowledge that connects Leader-member exchange with IWB through employee engagement.

\section{Literature Review}

\subsection{Theoretical Implication}

The study was grounded on Self Determination Theory (SDT). SDT addresses psychological needs related to autonomy, competence, and relatedness. Deci EL and Ryan RM [13] postulate that experience of autonomy, competence and relatedness is an avenue to self-determination which culminates into intrinsic motivation to pursue creativity and innovativeness among individuals. Autonomy is the freedom which comes with self-initiation and regulation of actions and tasks available. Deci Deci EL and Ryan RM [13] maintain that autonomy is a central tenet in innovativeness owing to the feeling of control that it elicits in individuals. They contend that competence relates to the acumen individuals possess, to attain internal and external outcomes, and to remain focused and effective while undertaking tasks and required actions. Through SDT, an employee's attitude which acts as a major driver of motivation is aligned with his or her behaviour, either at personal or at the professional level. The bottom line is that organizational productivity is a function of engaged employees, while engagement among employees is itself a function of employee motivation.

\subsection{Leader-Member Exchange and Innovative Work Behaviour}

Leader-members exchange is recognized as a dyadic theory of leadership which influences employees by the quality of the relationship existing between the management on one side, and employees' on the other [14]. Prior discourse on LMX theory indicates that the quality of the relationship that develops between employees and the management is, bound to vary in quality and as such most studies have gravitated around such variations in quality.

High-quality LMX interaction affects productive employees work behaviours through the employee engagement process [15]. Employees are encouraged to make efforts on behalf of their organizations focused on a high-quality relationship of exchange between the supervisor and the employees [16]. Hence, an employee's degree of engagement depends on an employee's understanding of the consistency of communication behaviours of leading members. Since companies should never push workers to participate but only encourage a good and trustworthy relationship with their employers.

$\mathrm{H}_{01}$ : Leader-Member exchange directly affects employee engagement

\subsection{Employee Engagement and Innovative Work Behaviour}

Employees who feel adequately engaged are more proactive in problem-solving, and in making networks of partners through which, new ideas are passed on, thereby enhancing chances of innovativeness [17, 18]. Previous studies have indeed confirmed that employee engagement is a precursor to innovative behaviour and creativity among employees. They argue that through engagement, collaborators can amass a wide network of personnel to involve in sharing ideas for enhancing innovative behaviour $[19,20]$.

Salanova M, Agut S and Peiró JM [21] contend that work engagement should be looked at from two perspectives. First, it should be seen as an outcome in itself and secondly, as an antecedent to innovative behaviour. Salanova M, Agut S and Peiró JM [21] posit that employee engagement is an independent construct which is likely to shape employees' perception of their work and by extension, their innovativeness.

$\mathrm{H}_{02}$ : Employee engagement significantly affects Innovative work behaviour.

\subsection{Leader-member Exchange and Innovative Work Behaviour}

The theory of leader-member exchange has emerged as an avenue for zeroing in on relations that exist between 
subordinates and their leaders [22]. According to the theory, leaders are expected to nurture differential connections with subordinates at the place of work $[14,23]$. In this way, differential workgroups composed of low quality to high-quality exchange are formed.

The bedrock for high-quality connections between subordinates and their leaders are tenets such as mutual respect, obligation, and trust in conjunction with the formal exchange of monetary rewards. On the contrary, low-quality LMX is a product of reliance on monetary exchange taking place as compensation to subordinates who are only considered as hired hands or simply put, employees whose rewards should only be in terms of monetary exchange [24, 25]. Indeed it has previously been demonstrated that LMX significantly impacts IWB among employees drawn from diverse sectors of business [26]. Other scholars have also reported similar findings.

Alsughayir A [27] for instance, tested the effect of LMX on IWB among supervisors and employees drawn from hotels in the Saudi Arabian context and confirmed that LMX positively and significantly predicted IWB. In another study, Kim M-S and Koo D-W [28] examined how LMX helps hotels to achieve innovative behaviour and job performance. LMX model based on theory was therefore developed to examine the connections among employee engagement, quality of LMX, innovative behaviour and job performance. Results revealed that job engagement was a function of LMX. However, organizational engagement was not significantly impacted by innovative behaviour.

$\mathrm{H}_{03}$ : Leader-member exchange significantly affects Innovative work behaviour

$\mathrm{H}_{04}$ : Employee engagement would indirectly affect the relationship between LMX and Innovative work behavior.

\section{Methodology}

This study adopted a cross- research method where data was gathered within a short period of two months from employees of 23 manufacturing firms in Nairobi County, Kenya. The explanatory research design was utilized for this research as it was deemed appropriate to determine the nature of the relationships between the variables [29]. Self-administered questionnaires were the key method used for data collection.

Further, the study employed stratified and systematic sampling techniques. Stratified sampling proceeded in two stages, with the first stage stratifying the identified firms into respective sectors, for purposes of establishing the exact number of employees to be drawn from the respective sectors. In the second stage, employees in each sector were stratified into respective firms within the sector. Finally, systematic sampling was adopted to ensure that each member had an equal probability of inclusion in the sample [30]. Under systematic sampling, selection of the first unit was done randomly, while the selection of all other units was done by picking the $i^{\text {th }}$ observation, where $i$ was determined by dividing the population by the required sample size. Systematic sampling was specifically used to constitute the sample of employees required from each firm.

\section{Research Analysis Findings \\ 4.1. Descriptive Statistical Tests, Reliability Analysis and Correlation Analysis}

The findings of descriptive statistics, reliability and correlation analysis are presented in Table 1 below. The table shows that Innovative work behaviour leads to the highest mean of 4.08, $(\mathrm{SD}=.569)$. This was followed by Leader-member exchange which had a mean of 3.73, $(\mathrm{SD}=.755)$ while Employee engagement had the least mean results of 3.72, $(\mathrm{SD}=.788)$. The table further reveals that all the variables had scale reliability above 0.8, with Employee engagement having the highest Cronbach' Alpha of .873, which was followed by IWB with .861 while LMX had the least score of .837 . Finally, the results of the Correlation analysis indicate that both LMX and engagement had a significant linear relationship with Innovative work behaviour. Employee engagement indicates the highest relationship with $\mathrm{r}=.521, p<.01$, while LMX has the weakest but significant relationship with $\mathrm{r}=.396, p<.01$. Consequently, the findings also reveal that Employee engagement has a significant association with LMX as shown by $\mathrm{r}=.450, p<.01$.

Table 1. Results of Means, standard deviations, reliability and correlation of the study

\begin{tabular}{llllll}
\hline Variable (n=384) & M & SD & Reliability & Correlation & \\
\hline IWB & 4.08 & .569 & .861 & 1 & \\
LMX & 3.73 & .755 & .837 & $.396^{* *}$ & 1 \\
EE & 3.72 & .788 & .873 & $.521^{* *}$ & $.450^{* *}$ \\
\hline
\end{tabular}

Note: Correlation is significant at $* * p<.01$, (2-tailed), $\mathrm{M}=\mathrm{Mean}, \mathrm{SD}=\mathrm{Standard}$ deviation.

\subsection{Factor Analysis}

This research used factor analysis before testing the hypotheses to check for construct validity. Thirty (30) objects were analyzed using Varimax rotation key component analysis. Innovative work behaviour had ten (10) items, Leader-Member Exchange eight (8) items and Employee engagement had twelve (12). Table 2 indicates the results of the three components which explained $51.6 \%$ of the variance, with Employee Engagement items loading as factor one (1) with only nine (9) items loading under it while 3 items were excluded because they did not meet the criteria as shown in Table 2. These items explained $9.996 \%$ of the total variance. Innovative work behaviour items loaded as factor two explaining $8.872 \%$ of the variance (Table 2) with eight (8) items loading and two (2) items excluded as they failed to load Table 2. Finally, LMX items loaded as factor three and explained a total of $32.714 \%$ variance as shown in Table 2, 
with six (6) items loading and two (2) item excluded (Table 2) as it failed to meet the required criteria. The Kaiser-Meyer-Olkin Measure of sampling adequacy (KMO) results show a score value of .882 with Bartlet's Test of
Sphericity showing a Chi-Square of 3863.328 with $\mathrm{df}=253$ being significant at .000 . Since KMO value is greater than .5 and Bartlett's test has a significant Chi-square, the findings confirmed the suitability of factor analysis.

Table 2. Factor Loadings.

\begin{tabular}{|c|c|c|c|}
\hline & \multicolumn{3}{|c|}{ Component } \\
\hline & EE & IWB & LMX \\
\hline I feel that my immediate supervisor understands my problems and needs & & & .751 \\
\hline My immediate supervisor recognizes my potential & & & .786 \\
\hline $\begin{array}{l}\text { Regardless of the amount of formal authority, my immediate supervisor has, I can count on him or her to "bail } \\
\text { me out" at his or her expense when I really need it }\end{array}$ & & & .654 \\
\hline My supervisor is the kind of person one would like to have as a friend. & & & .707 \\
\hline I respect my supervisor's knowledge of and competence on the job. & & & .565 \\
\hline I always look forward to coming to work & .641 & & \\
\hline I try my hardest to perform well on my job & .507 & & \\
\hline At work, my mind is focused on my job & 601 & & \\
\hline I feel strong and vigorous at the place of work. & .681 & & \\
\hline I exert a lot of energy on my work. & .598 & & \\
\hline I feel happy when I am working intensely. & .724 & & \\
\hline It is difficult to detach myself from my job & .725 & & \\
\hline When I am working, I forget everything else around me. & .737 & & \\
\hline I recognize opportunities to make a positive difference in my work, organization, department and customers & & .535 & \\
\hline I search out for new work methods, techniques or instruments & & .654 & \\
\hline I feel that I am good at finding new approaches of executing my tasks & & .662 & \\
\hline I encourage key organization members to be enthusiastic about innovative ideas & & .708 & \\
\hline I attempt to convince people to support innovative ideas & & .699 & \\
\hline I systematically introduce innovative ideas into work & & .691 & \\
\hline I contribute to implementation of new ideas & & .725 & \\
\hline I put effort into development of new things & & .691 & \\
\hline KMO, Bartlett's Test and Variance Explained & & & \\
\hline Eigen Values & 2.299 & 2.041 & 7.524 \\
\hline Percentage of Cvar & 42.710 & 51.583 & 32.714 \\
\hline Bartlett's Test of Sphericity Approx. Chi-Square & 3863.328 & & \\
\hline df & 253 & & \\
\hline Sig & .000 & & \\
\hline
\end{tabular}

Note: $\mathrm{EE}=$ Employee engagement, LMX=Leader-Member Exchange, IWB=Innovative work behaviour.

\subsection{Test of Hypothesis}

The study findings are all shown in Table 3. In the first step, as guided by MacKinnon, results indicate that LMX significantly affects Employee engagement with, $\beta=.378$, $p=.000$ (Table 3, column 1). Results further show that all control variables were found to be insignificant with all having $p>.05$. This model explains $20.8 \%$ of the variance in employee engagement as indicated by $\mathrm{R}^{2} .208$, with a significant $\mathrm{F}=19.858, p=.000$. Based on these findings, hypotheses $\mathrm{H} 1$ is supported by the study findings.

To test the second step, findings in Table 3, column 2 reveal that Employee engagement positively and significantly affects Innovative work behaviour as shown by $\beta=.377, p=.000$. All control variables in this model were also found to be insignificant as indicated by $p>.05$. Results show that this model accounted for $30.7 \%$ of the variance in Innovative work behaviour as shown by $\mathrm{R}^{2} .307$, with a significant $\mathrm{F}=27.841$, $\mathrm{p}<.000$. Since the results of employee engagement on Innovative work behaviour shows a significant effect as indicated by $p<.05$. Hypothesis $\mathrm{H} 2$ is also supported.

To establish the findings of the third step, testing the effect of the independent variable (LMX on Innovative work behaviour - path C' of Figure 1) while holding constant the mediating variable (Employee engagement), Hypothesis H3 was tested in the same column 2 of Table 3. Results of the study show that LMX was found to have a positive and significant effect on Innovative work behaviour as shown by $\beta=.159, p=.000$. Based on these results Hypothesis H3 is supported by the study.

To achieve the final step, the mediation effect was tested using a percentile bootstrap estimation approach with 5000 samples as represented in Table 3, column 3. The findings for the bias-corrected percentile bootstrap method indicate that the mediation effect of Leader-Member Exchange on Innovative work behaviour through Employee engagement was significant with the product of $a \times b$ showing a positive effect $=.142, \mathrm{SE}=.031,95 \% \mathrm{CI}=[.087, .207]$. Since both confidence intervals indicate nonzero, Hypothesis $\mathrm{H} 4$ was supported by study findings.

\subsection{Model Specification}

To check the hypotheses and the mediation effect of employee engagement between the independent variables and the dependent variable, the bootstrapping method was followed by testing the indirect effect as proposed by [31]. 
According to MacKinnon, the four conditions were checked as presented in Figure 1.

a) Independent variable (LMX) significantly predicts mediator variable (Employee engagement) (path $a$ of Figure 1- H1)

b) Mediator variable (Employee engagement) significantly predicts the dependent variable (Innovative work behaviour) (path $b$ of Figure 1- H2)

c) Independent variable (LMX) significantly predicts the dependent variable (Innovative work behaviour) while holding constant the mediator (path $C^{\prime}$ of Figure 1- H3). This does not need to be significant for mediation to take place.

d) A significant coefficient for the indirect path between LMX and Innovative work behaviour through employee engagement (product of $a_{1} \times b_{1}$ ). The bias-corrected percentile bootstrap method determines if this last condition is met (H4). The study included all the control variables in the analysis.

Table 3. Model description of the simple mediation model mentioned in "Figure 1" for the direct, indirect effect of employee engagement and LMX on IWB.

\begin{tabular}{|c|c|c|c|c|c|}
\hline \multirow[t]{2}{*}{ Study Variables } & \multicolumn{2}{|c|}{ Model 1 (EE) $a$} & \multicolumn{2}{|c|}{ Model 2 (IWB) $b_{1}$} & \multirow[t]{2}{*}{ Mediation (Model $3(a \times b)$} \\
\hline & $\beta$ & $p-v$ & $\beta$ & $p-v$ & \\
\hline Gender & -.081 & .198 & -.001 & .992 & \\
\hline Education & .030 & .451 & .001 & .975 & \\
\hline Experience & .068 & .516 & -.007 & .828 & \\
\hline Leader Member Exchange & $a=.378 * * *$ & .000 & $C^{\prime}=159 * * *$ & .000 & $\mathrm{axb}=.378 \times .377=.142$ \\
\hline Employee Engagement & - & - & $b=.377 * * *$ & .000 & $\mathrm{CI}=.087,207$ \\
\hline $\mathrm{R}^{2}$ & .208 & & .307 & & \\
\hline $\mathrm{F}$ & $19.858 * * *$ & & $27.841 * * *$ & & \\
\hline
\end{tabular}

Note: $* * * p .001$, Dependent variable: IWB=Innovative work behavior, EE=Employee engagement and LMX=Leader Member Exchange.

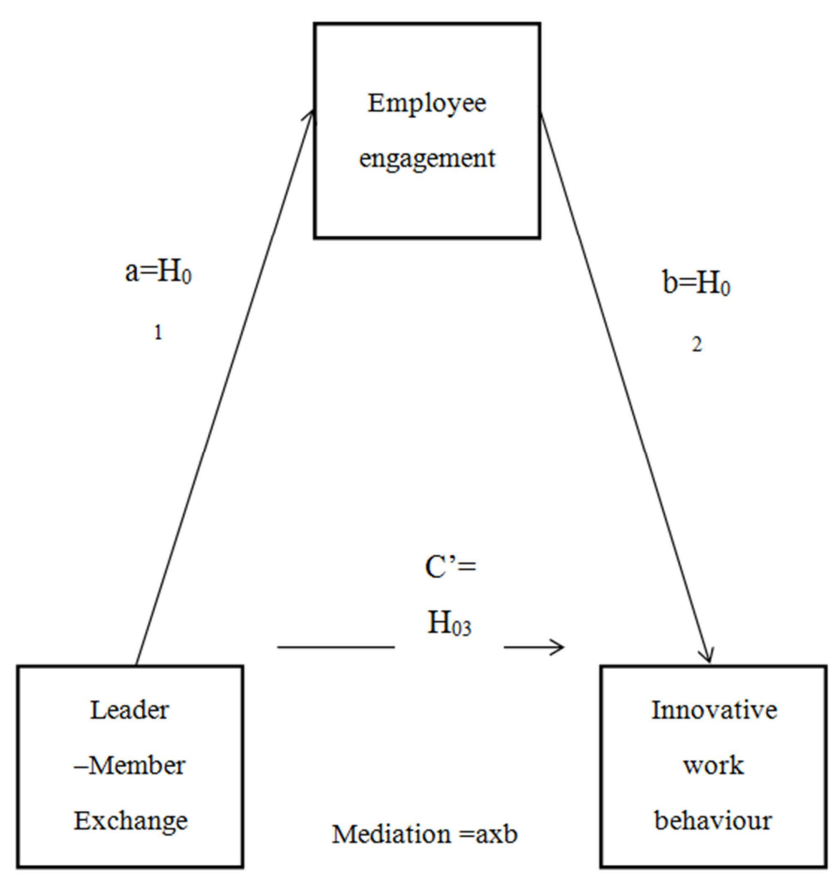

Source: Hayes AF and Preacher KJ [31].

Figure 1. Test for hypothesized mediation.

\section{Discussion and Conclusion}

The finding shows that LMX has a significant impact on employee engagement. These findings confirm that manufacturing firms are desirous of getting the best out of employees by nurturing symbiotic relationships of a mutual nature. Such relationships no doubt go a long way in stimulating innovative behaviour among employees. The findings show that supervisors understand employees problems and are at times on hand to help out with difficult tasks which reflects a high level of support, and are consistent with findings by [32] showing that supervisor support directly influences innovative behaviour. This is supported in accordance with the previous empirical literature and theory $[28,33]$. When there are support and resources from the leaders, the quality relationships is favourably correlated with favourable employee feelings; in this case employee engagement is seen by reciprocal respect, trust and liking [16, 28].

The behavioural and emotional engagement extended to employees in the manufacturing firms has seemingly impacted positively on their attitude values and commitment towards their work portraying a happy force. This may be argued that engaged employees offer all their ability to solve problems, interact with their colleagues effectively and improve innovation at work [28, 34]. The findings of this study are in agreement with the previous literature which found that highly engaged employees expressed innovative behaviours than low engaged employees [35]. This is also consistent with the work of Van der Heijden B and Spurk D [36] who conducted a study in Thai Airways International on Employee Engagement and Innovative Work Behavior. Their study indicates that engagement and innovation support each other and that engaged employees are expected to be more innovative in their workplace.

The exchange relationships between employees and their supervisors improve their efficiency and productivity by improving fresh ideas within the organizations. This means that when employees enjoy good relations with their supervisors, they feel valued, carry out their duties effectively, and are free to choose how to conduct their tasks. These will eventually contribute to significant organisation's results which may bring a rise in productivity of the organization. The results are consistent with earlier studies showing a positive relationship between LMX and innovative work behaviour [37-39]. These researchers have shown that LMX is an effective predictor of innovative work behaviour 
[40, 41]. Thus successful relationships between managers and workers inspire workers to be more innovative in their jobs.

The mediation model results bring new insights into literature that employee engagement has a partial mediating impact on the relationship between the Leader-member exchange and innovative work behaviour. Partial mediation means some, but not all, of the relationship between the independent variable and dependent variable, are compensated for by the mediating variable [42]. These results significantly contribute to the understanding that an organization should stimulate the ability of workers to make use of their robust efforts and skills in order to demonstrate innovative work innovative behaviour [43]. These findings are in line with the work of A. Agarwal U [44], who alludes that employees with a higher level of work engagement intended to participate in coming up with new ideas within an organisation. Thus, organisations that promote the creation of an innovative behaviour should put efforts to create and maintain an atmosphere that helps to encourage innovative work behaviour for employees by stressing job engagement as it positively affects employee's innovative work behaviour [46].

This research offers a comprehensively integrated model to explain the mediating impact of employee engagement on the relationship between the exchange of Leader members and creative work behaviour.

\section{Theoretical and Implication for Management}

In applying the self-determination theory advocated by Deci EL and Ryan RM [13], the researcher anticipated that besides the postulated relationships, internal drives can motivate an employee to be creative. The current study confirmed that intrinsic and extrinsic motivators were indeed critical in spurring employee innovative behaviour. The implication inherent in these findings is that discourse on interactions involving employee innovativeness should not rule out employees own determination to grow by being creative. Consequently, a richness of diverse theoretical underpinnings is indeed an ideal way to consider the construct of employee innovative work behaviour.

The study revealed that the interactions between employees and their supervisors have a direct impact on innovative work behaviour among the employees and in fact, it contributes a larger proportion of variance in innovative work behaviour than engagement. This should be taken seriously by the management of such firms.

\section{Limitations and Suggestion for Future Studies}

This study utilized a cross-sectional survey design which may not have determined the causal relationships between variables. Future research may use a longitudinal study to provide a deeper understanding of LMX's impact and creative work behaviour. A longitudinal survey is likely to provide causal effects of variables.

Although the current study's sample size was large, the study collected data from just one county in Kenya. For our findings to be validated, future studies should consider a wider area and a large target population.

Further, in collecting data from respondents a quantitative research approach was adopted. Future research should consider adopting a mixed-method approach by gathering both qualitative and quantitative data that can yield richer and more in-depth findings by revealing other issues that influence employees to become more innovative within the organization The research serves as a point of reference for those wishing to research the relationship between LMX and innovative work behaviour. The researchers could use any of these factors as mediators to determine if they can obtain similar results.

\section{Funding}

This research was partially supported by ASALI (A Sustainable Approach to Livelihood Improvement) Project.

\section{Acknowledgements}

I am indebted to my supervisors, Dr. Ambrose Kemboi and Dr. Joel Tenai, for their invaluable guidance and unwavering support throughout the process of developing of this research paper.

\section{References}

[1] De Spiegelaere S, Van Gyes G, De Witte H, Niesen W, Van Hootegem G: On the relation of job insecurity, job autonomy, innovative work behaviour and the mediating effect of work engagement. Creativity and innovation management 2014, 23: 318-330.

[2] Yuan F, Woodman RW: Innovative behavior in the workplace: The role of performance and image outcome expectations. Academy of management journal 2010, 53: 323-342.

[3] Alkhodary D: The relationship between employees' empowerment and innovative work behavior. International Journal of Managerial Studies and Research (IJMSR) 2016, 4: $1-15$.

[4] Bos-Nehles A, Renkema M, Janssen M: HRM and innovative work behaviour: A systematic literature review. Personnel review 2017, 46: 1228-1253.

[5] Jada UR, Mukhopadhyay S, Titiyal R: Empowering leadership and innovative work behavior: a moderated mediation examination. Journal of Knowledge Management 2019.

[6] Dan X, Xu S, Liu J, Hou R, Liu Y, Ma H: Relationships among structural empowerment, innovative behaviour, self-efficacy, and career success in nursing field in mainland China. International journal of nursing practice 2018, 24: e12674.

[7] De Spiegelaere S, Van Gyes G, De Witte H, Van Hootegem G: Job design, work engagement and innovative work behavior: A multi-level study on Karasek's learning hypothesis. management revue 2015: 123-137. 
[8] Abraham S: Job Satisfaction as an Antecedent to Employee Engagement. SIES Journal of Management 2012, 8.

[9] Schneider B, Macey WH, Barbera KM, Martin N: Driving customer satisfaction and financial success through employee engagement. People and Strategy 2009, 32: 22.

[10] Dulebohn JH, Bommer WH, Liden RC, Brouer RL, Ferris GR: A meta-analysis of antecedents and consequences of leader-member exchange: Integrating the past with an eye toward the future. Journal of management 2012, 38: 1715-1759.

[11] KAM: Kenya Association of Manufacturers. In Manufacturing in Kenya under the "Big 4 Agenda" 2018.

[12] KAM: Kenya Association of Manufacturers. 2018.

[13] Deci EL, Ryan RM: The" what" and" why" of goal pursuits: Human needs and the self-determination of behavior. Psychological inquiry 2000, 11: 227-268.

[14] Liden RC, Graen G: Generalizability of the vertical dyad linkage model of leadership. Academy of management journal 1980, 23: 451-465.

[15] Chaurasia S, Shukla A: The influence of leader-member exchange relations on employee engagement and work role performance. International Journal of Organization Theory and Behavior 2013, 16: 465.

[16] Brennan A: The Mediating Role of Optimism on The Relationship Between Leader Member Exchange (Lmx) and Employee Engagement: Evidence from the Irish Further Education and Training (Fet) Sector. Waterford Institute of Technology, 2017.

[17] Fatima A, Khan MA: Do hope foster innovative work behavior through employee engagement and knowledge sharing behavior? A conservation of resources approach using MPLUS tool. Business \& Economic Review 2017, 9: 181-212.

[18] Yean TF, Johari J, Yahya KK: The mediating role of learning goal orientation in the relationship between work engagement and innovative work behavior. International Review of Management and Marketing 2016, 6: 169-174.

[19] Scott SG, Bruce R: Creating innovative behavior among R\&D professionals: the moderating effect of leadership on the relationship between problem-solving style and innovation. In Proceedings of 1994 IEEE International Engineering Management Conference-IEMC'94. IEEE; 1994: 48-55.

[20] Shalley CE, Zhou J, Oldham GR: The effects of personal and contextual characteristics on creativity: Where should we go from here? Journal of management 2004, 30: 933-958.

[21] Salanova M, Agut S, Peiró JM: Linking organizational resources and work engagement to employee performance and customer loyalty: the mediation of service climate. Journal of Applied psychology 2005, 90: 1217.

[22] Gerstner CR, Day DV: Meta-Analytic review of leadermember exchange theory: Correlates and construct issues. Journal of Applied psychology 1997, 82: 827.

[23] Graen G, Cashman JF: A role-making model of leadership in formal organizations: A developmental approach. Leadership frontiers 1975, 143: 165.

[24] Graen GB, Uhl-Bien M: Relationship-based approach to leadership: Development of leader-member exchange (LMX) theory of leadership over 25 years: Applying a multi-level multi-domain perspective. The Leadership Quarterly 1995, 6: 219-247.

[25] Graen GB, Scandura TA: Toward a psychology of dyadic organizing. Research in organizational behavior 1987.

[26] Yeoh KK, Mahmood R: The relationship between pro-innovation organizational climate, leader-member exchange and innovative work behavior: A study among the knowledge workers of the knowledge intensive business services in Malaysia. Business Management Dynamics 2013, 2: 15-30.

[27] Alsughayir A: The effect of leader-member exchange on innovative work behavior in the Saudi hospitality. International Journal of Business and Management 2017, 12: 2017.

[28] Kim M-S, Koo D-W: Linking LMX, engagement, innovative behavior, and job performance in hotel employees. International Journal of Contemporary Hospitality Management 2017, 29: 3044-3062.

[29] Ivankova NV, Creswell JW, Stick SL: Using mixed-methods sequential explanatory design: From theory to practice. Field methods 2006, 18: 3-20.

[30] Sekaran U, Bougie R: Research methods for business: A skill building approach. John Wiley \& Sons; 2016.

[31] Hayes AF, Preacher KJ: Statistical mediation analysis with a multicategorical independent variable. British journal of mathematical and statistical psychology 2014, 67: 451-470.

[32] Qu R, Janssen O, Shi K: Leader-member exchange and follower creativity: the moderating roles of leader and follower expectations for creativity. The International Journal of Human Resource Management 2017, 28: 603-626.

[33] Tanskanen J, Mäkelä L, Viitala R: Linking managerial coaching and leader-member exchange on work engagement and performance. Journal of Happiness studies 2019, 20: 1217-1240.

[34] Hakanen JJ, Perhoniemi R, Toppinen-Tanner S: Positive gain spirals at work: From job resources to work engagement, personal initiative and work-unit innovativeness. Journal of vocational behavior 2008, 73: 78-91.

[35] Schaufeli WB, Bakker AB, Salanova M: The measurement of work engagement with a short questionnaire: A cross-national study. Educational and psychological measurement 2006, 66: 701-716.

[36] van Beek I, Taris TW, Schaufeli WB: Workaholic and work engaged employees: Dead ringers or worlds apart? Journal of Occupational Health Psychology 2011, 16: 468.

[37] Van der Heijden B, Spurk D: Moderating role of LMX and proactive coping in the relationship between learning value of the job and employability enhancement among academic staff employees. Career development international 2019, 24: 163-186.

[38] Altunoğlu AE, Gürel EBB: Effects of leader-member exchange and perceived organizational support on organizational innovation: The case of Denizli Technopark. Procedia-Social and Behavioral Sciences 2015, 207: 175-181. 
[39] Kheng YK, June S, Mahmood R: The determinants of innovative work behavior in the knowledge intensive business services sector in Malaysia. Asian Social Science 2013, 9: 47.

[40] Li X, Sanders K, Frenkel S: How leader-member exchange, work engagement and HRM consistency explain Chinese luxury hotel employees' job performance. International Journal of Hospitality Management 2012, 31: 1059-1066.

[41] Xerri M: Workplace relationships and the innovative behaviour of nursing employees: a social exchange perspective. Asia Pacific Journal of Human Resources 2013, 51: 103-123.

[42] Agarwal UA: Linking justice, trust and innovative work behaviour to work engagement. Personnel review 2014.

[43] Baron RM, Kenny DA: The moderator-mediator variable distinction in social psychological research: Conceptual, strategic, and statistical considerations. Journal of personality and social psychology 1986, 51: 1173.

[44] Para-González L, Jiménez-Jiménez D, Martínez-Lorente AR: Exploring the mediating effects between transformational leadership and organizational performance. Employee Relations 2018, 40: 412-432.

[45] A. Agarwal U: Linking justice, trust and innovative work behaviour to work engagement. Personnel Review 2014, 43: 41-73.

[46] Li H, Sajjad N, Wang Q, Muhammad Ali A, Khaqan Z, Amina S: Influence of transformational leadership on employees' innovative work behavior in sustainable organizations: Test of mediation and moderation processes. Sustainability 2019, 11: 1594. 